\title{
Mealy-Ant Association, Distribution and Extent of Damage Caused by Maconellicoccus hirsutus (Hemiptera: Pseudococcidae) on its Various Host Plants in Vadodara, Gujarat
}

\author{
Mamata Deb, Dolly Kumar* \\ Division of Entomology, Department of Zoology, Faculty of Science, The M.S. University of Baroda, Vadodara-390002, India
}

\begin{abstract}
A study conducted in the agricultural fields of Vadodara documented the incidence of Maconellicoccus hirsutus as one of the growing pests of the city. Hence the objective is to study the behavior of the pest to come out with an eco-friendly control measure before it crosses the economic injury level. Regular visits were made to different agricultural fields and community gardens of Vadodara to study the morphology, biology, distribution of the pest and its relation with its biotic and abiotic factors for a period of two years i.e. April 2013 - April 2015. The type \& extent of damage on different host plants was also studied. Major infestation was evidenced from Annona squamosa followed by Hibiscus rosa-sinensis with significant infestation on Gossypium hirsutum. Adult females and nymphs were recorded to be the major infesting stages. Extent of damage was found maximum during winter months i.e. from November to February. Moreover, Mealy-ant association is a unique behavior reported which they employ for mutual benefit. Use of chemical pesticides prevails in the city which could be a probable reason for growing mealybug population. Hence such studies hold the base of IPM and needed to design an eco-friendly way for controlling the pest.
\end{abstract}

Keywords: Distribution, Extent of damage, Host plants, Maconellicoccus hirsutus, Mealy-ant association

\section{Introduction}

Maconellicoccus hirsutus (Green, 1908), the Pink Hibiscus Mealybug (Phm) is a pest which has a wide range of hosts starting from economically important crops like Gossypium hirsutum to Hibiscus rosa-sinensis, which is an ornamental plant $[6,13]$. Wide range of hosts has supported its rapid migration in different parts of the world including the tropical and subtropical areas of the new world especially in 24 Caribbean islands where it causes havoc in different agricultural fields [22]. Phm is originally known to belong to Southern Asia from where it extended its range in North and Central America [27]. Moreover studies revealed that pink hibiscus mealybug was recorded as a major pest in Karnataka, India during 2003 [1]. Maconellicoccus hirsutus was also seen to infest the hibiscus and cotton plants in the Vadodara city of Gujarat [25]. A study carried out by the agricultural department of United states reported the migration of Maconellicoccus hirsutus to different states of India i.e. Andhra Pradesh, Assam, Delhi, Bihar, Karnataka, Kerala, Madhya Pradesh, Maharashtra, Orissa, Punjab, Tamil Nadu, Tripura, Uttar Pradesh, West Bengal [14]. To facilitate the understanding of the type of damage caused by the hibiscus mealybug, all instars were identified and described morphologically so that unnecessary use of chemical pesticides can be avoided [19]. Most preferable host plant of Hibiscus mealybug is Hibiscus rosa-sinensis where it destroys the visual effect of this ornamental plant [15]. Studies also revealed that Annona squamosa as one of the host plants of Phm [11]. Further studies reported that Maconellicoccus hirsutus causes great infestation to the cotton plants of all the nine cotton growing states of India
[18]. Hibiscus mealybug is also reported to cause major damage in the cotton fields of Marathwada region, Maharashtra first time in 2006 [2]. Moreover, it is known to infest the grape severely where it affects $50-100 \%$ of its production [26].

Apart from the wide host range, factor that supported its growth is their mutual association with different species of ants. Studies revealed that increase in mealybug infestation is positively correlated with the ant population [21]. Ants were established to facilitate the growth of different species of mealybugs thus aids in to the infestation of the respective host plant [10].

From the above review it is clear that Hibiscus mealybug is an invasive pest which causes significant damage to its host plants. Thus the present study will help in understanding the range of host plants and the extent of damage in Vadodara city so that proper control measures can be implemented for controlling this invasive species.

\section{Materials and Methods}

\section{Field Survey}

Field survey was purely random in the beginning to locate the incidence of Maconellicoccus hirsutus and their level of infestation in different host plants. Four different ecological sites were selected post survey for carrying out the present study (Table 1). Field visits were done regularly once in a week during the study period i.e. from April 2013 to April 2015. 
International Journal of Science and Research (IJSR)

ISSN (Online): 2319-7064

Index Copernicus Value (2013): 6.14 | Impact Factor (2015): 6.391

Table 1: Details of the Study sites, plantation and Mealybug infestation

\begin{tabular}{|c|c|c|c|c|c|}
\hline Sr.no. & $\begin{array}{l}\text { Study } \\
\text { Sites }\end{array}$ & Name \& description & $\begin{array}{c}\text { Distance and direction } \\
\text { from Vadodara }\end{array}$ & Crop plants & Mealybug infestation \\
\hline 1 & \multirow[t]{3}{*}{ Site 1} & $\begin{array}{l}\text { Chhani mainly comprises of } \\
\text { agricultural fields in an area of } \\
2.5 \text { hacters }\end{array}$ & 15 Kms. on the North. & $\begin{array}{c}\text { Gossypium hirsutum, Ricinus } \\
\text { communis, Abelmoschus } \\
\text { esculentus, Solanum melongena }\end{array}$ & $\begin{array}{l}\text { Major infestation on Cotton. } \\
\text { No infestation on Castor, Okra } \\
\text { and Brinjal }\end{array}$ \\
\hline 2 & & $\begin{array}{c}\text { Waghodia encompasses more } \\
\text { than } 4 \text { hactares of land which is } \\
\text { largely used for agricultural } \\
\text { plantations }\end{array}$ & $15 \mathrm{Kms}$. on the East. & $\begin{array}{c}\text { Gossypium hirsutum, Hibiscus } \\
\text { rosa-sinensis, Solanum } \\
\text { melongena, Oryza sativa, } \\
\text { Triticum aestivum }\end{array}$ & $\begin{array}{c}\text { Major infestation on Hibiscus } \\
\text { and Cotton. No infestation on } \\
\text { Brinjal, Paddy and wheat }\end{array}$ \\
\hline 3 & & $\begin{array}{l}\text { Mostly agricultural fields are } \\
\text { found in Dabhoi spread in an } \\
\text { area of approx. } 4.3 \text { hactares }\end{array}$ & $\begin{array}{l}30 \text { Kms. on the } \\
\text { Southeast. }\end{array}$ & $\begin{array}{c}\text { Gossypium hirsutum, Zea maize, } \\
\text { Triticum aestivum }\end{array}$ & $\begin{array}{c}\text { Major infestation on Cotton } \\
\text { No infestation on Maize and } \\
\text { Wheat }\end{array}$ \\
\hline 4 & Site 2 & $\begin{array}{l}\text { Kamatibaug, a community } \\
\text { garden located at the heart of the } \\
\text { vadodara city in an area of } \\
\text { approx. } 46 \text { hactares }\end{array}$ & $\begin{array}{l}\text { Within Vadodara city, } \\
\text { Sayajigunj }\end{array}$ & $\begin{array}{c}\text { Azadirechta indica, } \\
\text { Ficusbangalensis, Lantana } \\
\text { camara, Hibiscus rosa-sinensis, } \\
\text { Nerium odorumetc }\end{array}$ & $\begin{array}{l}\text { Infestation was seen in } \\
\text { Hibiscus rosa-sinensis }\end{array}$ \\
\hline 5 & Site 3 & $\begin{array}{l}\text { Arboretum managed by the } \\
\text { department of botany, The } \\
\text { M.S.University of Baroda, } \\
\text { Vadodara }\end{array}$ & $\begin{array}{l}\text { Within Vadodara city, } \\
\text { Pratapgunj }\end{array}$ & $\begin{array}{l}\text { Hibiscus rosa sinensis, Annona } \\
\text { reticulate, Annona squamosa, } \\
\text { Neuracanthus sphaerostachys } \\
\text { Dalz etc. }\end{array}$ & $\begin{array}{l}\text { Major infestation on Annona } \\
\text { squamosa was recorded }\end{array}$ \\
\hline 6 & Site 4 & $\begin{array}{c}\text { Botanical garden is an extension } \\
\text { of botany department of The } \\
\text { M.S. University of Baroda, } \\
\text { Vadodara }\end{array}$ & $\begin{array}{l}\text { Within Vadodara city, } \\
\text { Sayajigunj }\end{array}$ & $\begin{array}{c}\text { Hibiscus rosa sinensis, Annona } \\
\text { squamosa, Manilkara zapota, } \\
\text { Lantana camara etc. }\end{array}$ & $\begin{array}{l}\text { Major infestation on Annona } \\
\text { squamosa was recorded }\end{array}$ \\
\hline
\end{tabular}

\section{Sampling}

Sampling was done from the above mentioned sites (Table 1). Mealybugs were collected gently using Camel paint brush to avoid injuries to this delicate pest. Heavily infested plant parts were collected and brought to the laboratory along with the pest for identification. Mealybugs were then separated with the help of the brush and transferred into the glass vials filled with $70 \%$ methanol. The vials were then labeled and a few pests were preserved for future reference.

\section{Identification}

Preserved mealybugs were identified using stereomicroscope considering different morphological characters. Identification was then confirmed using standard citations [16]. Both the stages i.e. adults and nymphs were preserved for future reference.

\section{Distribution and Host range}

Identification of most preferred host plants and distribution of Maconellicoccus hirsutus were studied through field surveys and proper sampling of this invasive pest were done from the selected sites.

\section{Extent of Damage}

Assessment of damage caused by this pest in the agricultural fields, community garden and arboretum was also done during survey period itself. Severity of damage was studied thoroughly in the fields with the help of the magnifying glass. Heavily infested stems were brought to the laboratory and studied under the low-power microscope.

\section{Control measures}

Damages caused by Maconellicoccus hirsutus require proper control measures to avoid its multiplication and migration to different regions. Use of Chemical pesticides is the most common control measure seen in the agricultural fields of Vadodara. Regular interview with the farmers and detailed field survey revealed the story about the heavy use of chemical pesticides.

\section{Results and Discussion}

\section{Distribution and Host Range}

Maconellicoccus hirsutus (Hibiscus mealybug) was reported to infest 3 host plants viz. Annona squamosa, Hibiscus rosa sinensis and Gosssypium hirsutum from Vadodara. Mealybugs start appearing in fields in the month of October and reaches to its maximum population during January which continues till February. The number then gradually decreases and finally vanishes by the end of March. Winter months are best suitable for their growth and multiplication because of the mild temperature $\left(\max .33 .56^{\circ} \mathrm{C}\right.$ and min. $12.32{ }^{\circ} \mathrm{C}$ ) and humidity (50-60\% RH). Moreover, Annona squamosa was established as the most preferable host plant of Phm than to hibiscus and cotton in Vadodara. 


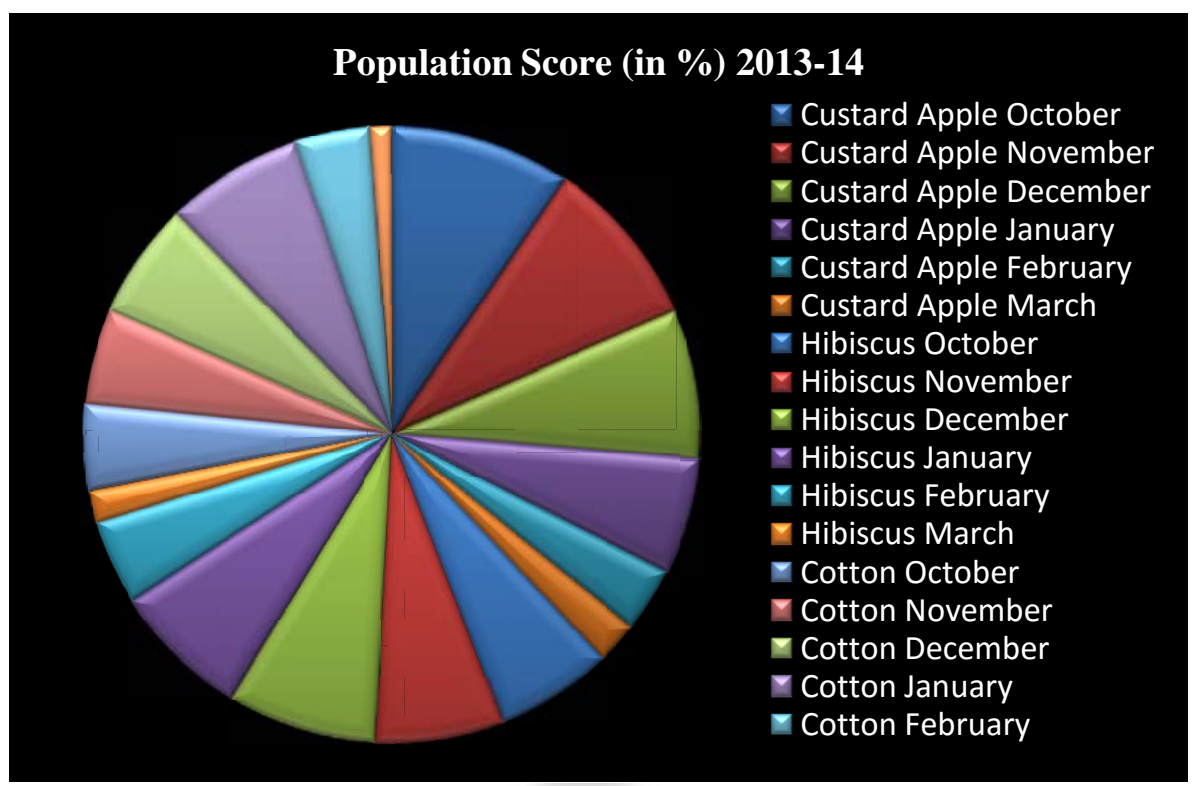

Graph 1: Population score of Phm in the host plants in different months of winter during 2013-14

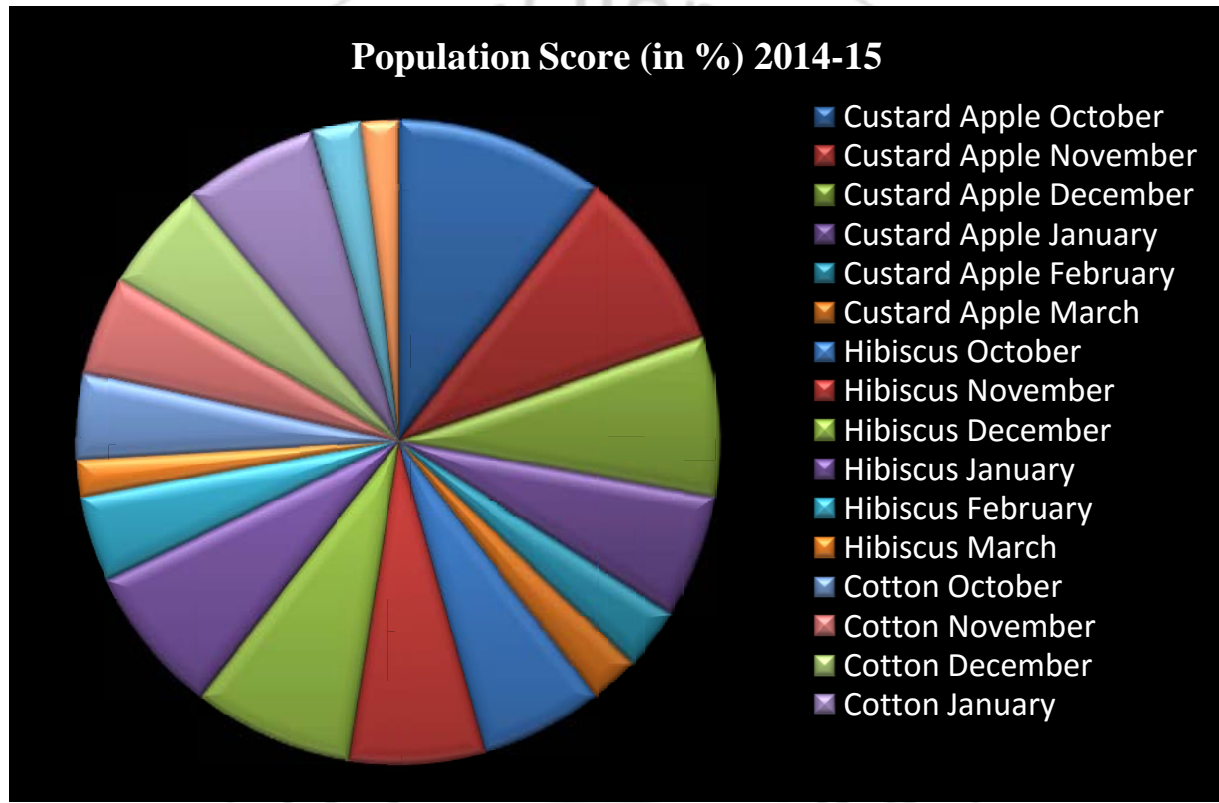

Graph 2: Population score of Phm in the host plants in different months of winter during 2014-15

Among the selected sites, Arboretum and Botanical garden which have the plantation of Annona squamosa has been reported with the infestation of $\mathrm{Phm}$ in the month of October. Other sites which include agricultural fields and community garden have plantation of Cotton and hibiscus respectively experienced infestation at the end of the December. Difference in the onset of mealybug infestation is due to the difference in fruiting season of three host plants. Fruiting season of custard apple starts in august whereas other two host plants experiences a delayed fruiting/flowering season i.e. in December. As the winter progresses infestation of Hibiscus mealybug also reaches to its maximum level. In a relevant work authors used Hibiscus rosa sinensis as a host plant for rearing and breeding of Maconellicoccus hirsutus [4]. Host range of Phm is very wide starting from edible vegetables till ornamentals so known to invade different areas [20]. Akin studies were performed in Brazil which used tomatoes for growing three different mealybug species [5]. Use of vegetables like
Japanese pumpkin and squash as host plants yield positive results [23].

\section{Symptoms of Damage}

Infestation caused by the Maconellicoccus hirsutus can be categorized into two types i.e. mild infestation and heavy infestation (Figure 1). Mildly infested plants were tough to identify because mealybugs appear as white beads in different parts of the plants predominantly in the apical shoot region. Thorough field survey is required to identify mild infestation in the fields. Heavily infested plants could be recognized from a distance of a mile because of their characteristic white waxy secretion which covers their body. Mealybugs known to cause great damage to its host plant which leads to the total destruction of the crop [9].

Generally nymphal stages remains attached to the apical part of the young shoot. Hibiscus mealybug migrates to different parts of the host plants as they multiply in number. 
International Journal of Science and Research (IJSR)

ISSN (Online): 2319-7064

Index Copernicus Value (2013): 6.14 | Impact Factor (2015): 6.391

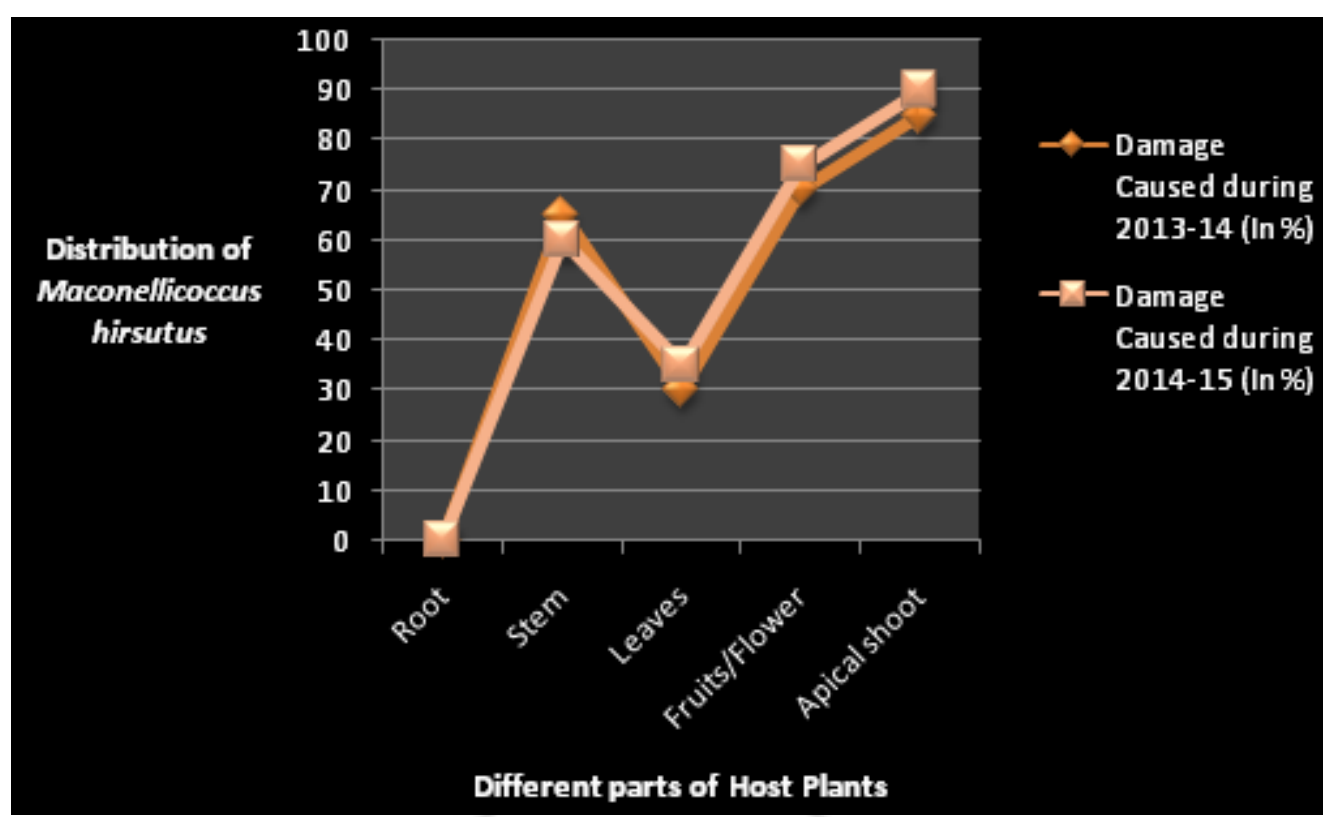

Graph 3: Distribution of Maconellicoccus hirsutus in different parts of their host plants (Annona squamosa, Hibiscus rosa sinensis and Gossypium hirsutum) and their extent of damage

Among the other symptoms of Phm damage, deformed leaves and fruits, distortion of the stem and early dropping of leaves and fruits were prevalent. Moreover, a sticky product of their excretion known as Honeydew is a suitable media for fungal growth. This turns the leaves black and thus interferes with the mechanism of photosynthesis. As a result the plant deteriorates within a few days.

\section{Assessment of Damage}

During the two years study conducted from 2013-2015, revealed that an average of $80 \%$ custard apple, $60 \%$ hibiscus and $40 \%$ cotton were damaged by the mealybugs. Major infestation was recorded in Custard Apple (Figure 2), Hibiscus being the second and Cotton showed comparatively least infestation. One significant observation seen during the study was the gradual decrease in the infestation of Maconellicoccus hirsutus with the progressing year. Level of infestation seen during 2013 gradually lowered in Hibiscus \& Cotton during 2014 and 2015. On the other hand, no changes in the infestation level in Annona squamosa were recorded. Affected plants which remain untreated died whereas plants which are treated after the $2 / 4$ th of infestation showed poor production.

Table 2: Correlation between the Mealybug population and

\begin{tabular}{|c|c|} 
the extent of damage caused to Host plants \\
\hline $\begin{array}{c}\text { Population } \\
\text { score (In \%) }\end{array}$ & Extent of Damage \\
\hline $0-20$ & Attack apical shoot region \\
\hline $20-40$ & Affects apical shoot and stem \\
\hline $40-60$ & Affects apical shoot, stem and leaves \\
\hline $60-80$ & Apical shoot, stem and leaves and fruit \\
& affected \\
\hline $80-100$ & Whole plant is affected \\
\hline
\end{tabular}

Maconellicoccus hirsutus was reported as a growing pest in the fields of Vadodara along with another species i.e. Phenacoccus solenopsis which is known to cause disasters in the agricultural fields of Vadodara [24]. In a similar study carried out in U.S. reported Phm as a major polyphagus pest of the area among 158 species of mealybugs [17].

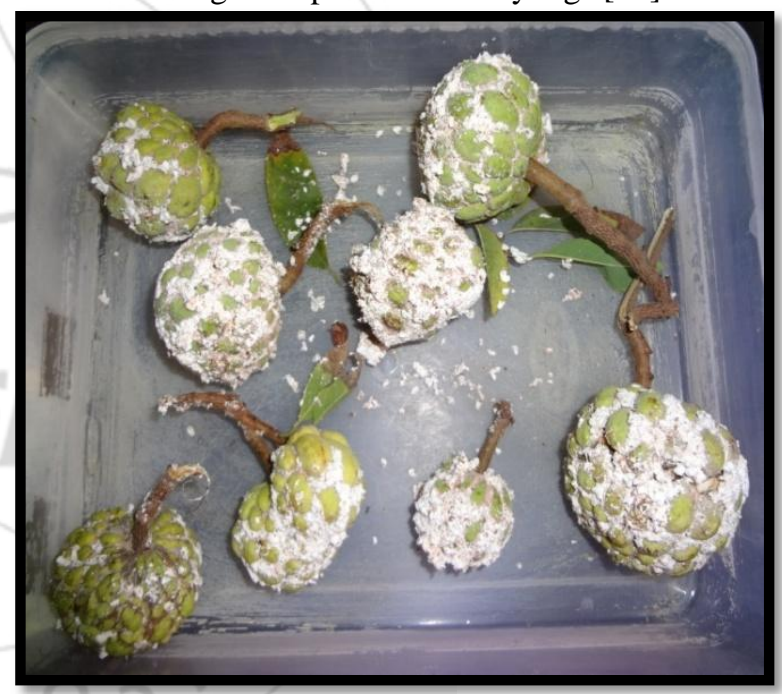

Figure 1: Heavily infested fruits of Annona squamosa with Maconellicoccus hirsutus

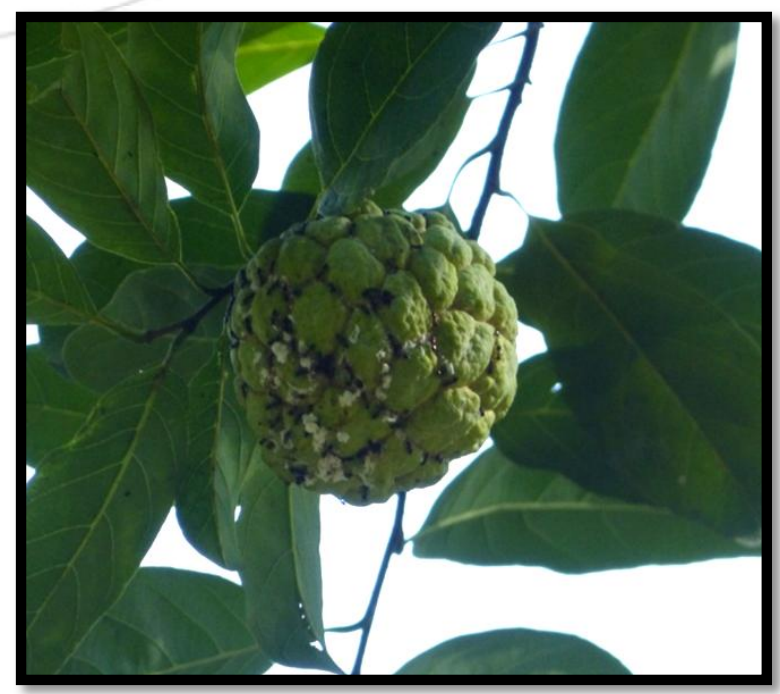

Figure 2: Mealy- ant association 


\section{International Journal of Science and Research (IJSR) \\ ISSN (Online): 2319-7064 \\ Index Copernicus Value (2013): 6.14 | Impact Factor (2015): 6.391}

\section{Mealy- Ant Association}

Mealybug ant association is an example of mutual relationship (Figure 2). This tiny pest was recorded to be protected by the Formicid social insect. Ants were found to gather around the colonies of Phm for feeding on honeydew which in turn protects the pest against predators. The species of ant seen around the Phm colonies were Camponotus compressus belong to the family Formicidae. In a recent survey carried out in Tamil Nadu reported the association of Maconellicoccus hirsutus and ants in Mulberry ecosystem [12]. Also studies were done which revealed that an invasive species of ant facilitates the growth of two different mealybug species [8]. Moreover, Honeydew secreted by the homopterans established to act as one of the energy source for ant population which in turn defends the group from their predators [7]. Adding to this survey, it was hypothesized that better protection was seen in mealybugs when more aggressive ants are around [3].

\section{Control Measures}

Use of chemical pesticides is the most common control measure seen in the fields of Vadodara. Two groups of pesticides namely Organophosphate and Synthetic pyrethroids are used regularly in the fields of Vadodara to control almost all insect pests including Maconellicoccus hirsutus. Moreover, discussion with the farmers revealed that Hibiscus mealybug has become unresponsive to these pesticides whereas earlier the same were efficient in controlling these Hemipteran pests.

\section{Conclusion}

The growing infestation of Maconellicoccus hirsutus (Green) in the Vadodara was transparent during the survey. This insect pest was recorded to infest a large number of host plants around the globe hence a matter of concern. It has a wide host range from economically important crops to ornamental plants. Though Annona squamosa is reported to be the major host plant of Pink hibiscus mealybug but it is also reported to cause significant loss to Cotton and Hibiscus in Vadodara. Individual use of chemical pesticide will not have profound effect and so it is recommended to implement the IPM strategies along with the pesticides to control this invasive pest.

\section{Acknowledgement}

Authors are grateful to the Department of Biotechnology (DBT), Ministry of Science and Technology, New Delhi for the financial support in carrying out this project work.

\section{References}

[1] Balikai R A \& Kotikal Y K. 2003. Pest status of grapevine in northern Karnataka. Agricultural Science Digest 23(4): 276-278.

[2] Bhoslfj B. 2009. Management of mealybugs (Phanacoccus solenopsis) in rainfed cotton (Gossypium hirsutum). Indian Journal of Agricultural Sciences 79(3):199-202.

[3] Buckley R and Gullan P. 1991. More aggressive ant species (Hymenoptera: Formicidae) provide better protection for soft scales and mealybugs (Homoptera: Coccidae, Pseudococcidae). Biotropica 23(3): 282-286.

[4] Chong J H, Roda A L \& Mannion C M. 2008. Life history of the mealybug, Maconellicoccus hirsutus (Hemiptera: Pseudococcidae), at constant temperatures. Environmental entomology 37(2): 323-332.

[5] Culik M P and Gullan P J. 2005. A new pest of tomato and other records of mealybugs (Hemiptera: Pseudococcidae) from Espirito Santo, Brazil. Zootaxa, 964: 1-8.

[6] Culik M P, Fornazier M J, dos Santos Martins D, ZanuncioJr J S, Ventura J A, Peronti A L B and Zanuncio J C. 2013. The invasive mealybug Maconellicoccus hirsutus: lessons for its current range expansion in South America and invasive pest management in general. Journal of pest science 86(3): 387-398.

[7] Helms K R and Vinson S B. 2002. Widespread association of the invasive ant Solenopsis invicta with an invasive mealybug. Ecology 83(9): 2425-2438.

[8] Helms K R and Vinson S B. 2003. Apparent facilitation of an invasive mealybug by an invasive ant. Insectes Sociaux 50(4): 403-404.

[9] Hoy M A, Hamon A and Nguyen R. 2002. Pink hibiscus mealybug, Maconellicoccus hirsutus (Green). Florida Cooperative Extension Service. Institute of Food and Agriculture Sciences. University of Florida. Publication number: EENY-29, 6.

[10] Jahn G C, Beardsley J W and González-Hernández H. 2003. A review of the association of ants with mealybug wilt disease of pineapple. Proc. Hawaiian Entomol Soc 36:9-28.

[11] Kairo M T, Pollard G V, Peterkin D D and Lopez V F. 2000. Biological control of the hibiscus mealybug, Maconellicoccus hirsutus Green (Hemiptera: Pseudococcidae) in the Caribbean. Integrated Pest Management Reviews 5(4): 241-254.

[12] Mahimasanthi A, Sakthivel N, Nalini R and Rajavel S. 2014. Association of ants with pink hibiscus mealybug, Maconellicoccus hirsutus (Green) and its influence on predatory fauna in mulberry ecosystem. Journal of Biopesticides 7(1): 47-51.

[13] MarsaroJúnior A L, Peronti A L B G, Penteado-Dias A M, Morais E G F and Pereira P D S. 2013. First report of Maconellicoccus hirsutus (Green, 1908) (Hemiptera: Coccoidea: Pseudococcidae) and the associated parasitoid Anagyrus kamali Moursi, 1948 (Hymenoptera: Encyrtidae), in Brazil. Brazilian Journal of Biology 73(2): 413-418.

[14] Meyerdirk D E, Warkentin R, Attavian B, Gersabeck E, Francis A, Adams J and Francis G. 2001. Biological control of pink hibiscus mealybug project manual. Agricultural Department, USDA, Washington D.C. pp 121-127.

[15] Michaud J P and Evans G A. 2000. Current status of pink hibiscus mealybug in Puerto Rico including a key to parasitoid species. The Florida Entomologist 83(1): 97-101.

[16] Miller D R. 1999. Identification of the Pink Hibiscus Mealybug, Maconellicoccus hirsutus(Green) (Hemiptera: Sternorrhyncha: Pseudococcidae). Insecta Mundi (paper339) 13 (3-4): 189 - 203. 
[17] Miller D R, Miller G L and Watson G W. 2002. Invasive species of mealybugs (Hemiptera: Pseudococcidae) and their threat to US agriculture. ProceedingsEntomological Society of Washington 104(4): 825-836.

[18] Nagrare V S, Kranthi S, Biradar V K, Zade N N, Sangode V, Kakde G and Kranthi K R. 2009. Widespread infestation of the exotic mealybug species, Phenacoccus solenopsis (Tinsley) (Hemiptera: Pseudococcidae), on cotton in India. Bulletin of entomological research 99(5):537-541.

[19] Pena J E. 1998. Current and potential arthropod pests threatening tropical fruit crops in Florida. Proceedings of the Florida State Horticultural Society 111: 327-329.

[20] Persad A and Khan A. 2007. Effects of four host plants on biological parameters of Maconellicoccus hirsutus Green (Homoptera: Pseudococcidae) and efficacy of Anagyrus kamali Moursi (Hymenoptera: Encyrtidae). Journal of Plant Protection Research 47(1): 35-42.

[21] Phillips P and Sherk C. 1991. To control mealybugs, stop honeydew-seeking ants. California Agriculture 45(2): 26-28.

[22] Sagarra L A and Peterkin D D. 1999. Invasion of the Caribbean by the hibiscus mealybug, Maconellicoccus hirsutus Green (Homoptera: Pseudococcidae). Phytoprotection 80(2): 103-113.

[23] Serrano M S and Lapointe S L. 2002. Evaluation of host plants and a meridic diet for rearing Maconellicoccus hirsutus (Hemiptera: Pseudococcidae) and its parasitoid Anagyrus kamali (Hymenoptera: Encyrtidae). Florida Entomologist 85(3): 417-425.

[24] Singh A and Kumar D. 2012. Population dynamics, biology of mealybug Phenacoccus solenopsis (Tinsley) and its natural enemies in Vadodara, Gujarat. Recent Research in Science \& Technology 4(11): 22-27.

[25] Singh A. 2012. Adoption of Bio-rational alternatives to pesticides in selected agricultural crops. P.hD. Thesis submitted to The Maharaja Sayajirao University of Baroda, Vadodara, Gujarat (India).

[26] Tanwar R K, Jeyakumar P and Monga D. 2007. Mealybugs and their management. NCIPM Technical Bulletin 19: 1-12.

[27] Williams D J. 1996. A brief account of the hibiscus mealybug Maconellicoccus hirsutus (Hemiptera: Pseudococcidae), a pest of agriculture and horticulture, with descriptions of two related species from southern Asia. Bulletin of Entomological Research 86(5): 617628. 